University of Nebraska - Lincoln

DigitalCommons@University of Nebraska - Lincoln

Papers in Natural Resources

Natural Resources, School of

2011

The Influence of Habitat and Environment on Smallmouth Bass (Micropterus dolomieu) Nest Sites and Nest Success in Northern Lake Michigan

Mark A. Kaemingk

University of Nebraska - Lincoln, mkaemingk2@unl.edu

Alexander Clem

Central Michigan University

Tracy L. Galarowicz

Central Michigan University, galar1tl@cmich.edu

Follow this and additional works at: https://digitalcommons.unl.edu/natrespapers

Part of the Natural Resources and Conservation Commons, Natural Resources Management and Policy Commons, and the Other Environmental Sciences Commons

Kaemingk, Mark A.; Clem, Alexander; and Galarowicz, Tracy L., "The Influence of Habitat and Environment on Smallmouth Bass (Micropterus dolomieu) Nest Sites and Nest Success in Northern Lake Michigan" (2011). Papers in Natural Resources. 698.

https://digitalcommons.unl.edu/natrespapers/698

This Article is brought to you for free and open access by the Natural Resources, School of at DigitalCommons@University of Nebraska - Lincoln. It has been accepted for inclusion in Papers in Natural Resources by an authorized administrator of DigitalCommons@University of Nebraska - Lincoln. 
Published in Journal of Great Lakes Research 37 (2011), pp 380-385.

doi:10.1016/j.jglr.2011.03.002

Published by Elsevier B.V. on behalf of International Association for Great Lakes Research.

Used by permission.

Submitted 24 August 2010; accepted 11 February 2011; published 29 March 2011.

\title{
The influence of habitat and environment on smallmouth bass (Micropterus dolomieu) nest sites and nest success in northern Lake Michigan
}

\author{
Mark A. Kaemingk, Alexander Clem, and \\ Tracy L. Galarowicz \\ Central Michigan University, Department of Biology, Brooks Hall 217, \\ Mt. Pleasant, MI 48859, USA \\ Corresponding author - M. A. Kaemingk email mkaemingk2@unl.edu
}

\begin{abstract}
Information on smallmouth bass nesting ecology is lacking in northern Lake Michigan, despite available information for other Great Lakes ecosystems. Our objectives were to identify factors that influenced nesting sites and nest success in a smallmouth bass population in northern Lake Michigan. Temperature, substrate firmness, and lake bottom rugosity were measured and related to the number of smallmouth bass nests in four bays. We also investigated the role of temperature, effective fetch, and storms to explain nest success. Temperature appeared to be most important in explaining the number of nests and nest success; transects that experienced the greatest number of cumulative degree days above $15{ }^{\circ} \mathrm{C}$ during nesting contained more nests and increased nest success. Our results suggest that warmer areas during spawning in northern latitude lentic systems should be protected from anthropogenic disturbances because these areas may be important for future recruitment of smallmouth bass.
\end{abstract}

Keywords: Smallmouth bass, Nest survival, Lake Michigan, Habitat, Temperature 


\section{Introduction}

Basic habitat selection models imply that an individual searches all suitable habitats and selects one where conditions are most favorable, resulting in increased fitness. In habitats that are somewhat predictable, an individual is less likely to move after reproductive success (Switzer, 1993). Among fishes, the relationship of selecting nest sites based on future fitness is not well understood. Warner (1988) suggested that, in some cases, consistency between years in spawning sites among fishes may be more related to traditionality (i.e., consistently using the same site each year despite the quality of habitat) as opposed to either past reproductive success or available resources; however, once tradition is broken, nest site selection is based on resource quality and not randomly selected (Warner, 1990).

Smallmouth bass (Micropterus dolomieu) often exhibit nest site fidelity where a majority of males will nest within 10om of their spawning site from a previous year (Ridgway et al., 1991a). The tendency for smallmouth bass to remain in close proximity to previous spawning sites suggests that habitat features are consistent among years and may influence nest site selection (Rejwan et al., 1997). Habitat characteristics thought to influence nest site selection include temperature and shoreline complexity (Rejwan et al., 1999). In addition, smallmouth bass nest success, as defined by smallmouth bass fry reaching the free swimming stage (Ridgway, 1989; Steinhart et al., 2005a), has previously been related to storms or high winds (Goff, 1986; Steinhart et al., 2005a), angling (Philipp et al., 1997; Suski et al., 2002; Steinhart et al., 2005a), temperature (Lukas and Orth, 1995), nest predators (Steinhart et al., 2005b), large scale climate patterns (Suski and Ridgway, 2007), and body size (Lukas and Orth, 1995; Suski and Ridgway, 2007).

Although smallmouth bass nest survival in relation to habitat variables in the Great Lakes have been examined in Lake Erie (Goff, 1986; Steinhart et al., 2005a), no studies to our knowledge relate environmental and habitat variables to smallmouth bass nest survival and nest densities in northern Lake Michigan. The Beaver Archipelago (i.e., northern Lake Michigan) and the Lake Erie ecosystems differ in productivity, nest predator densities, and permission of angling during spawning. Lake Erie exhibits higher productivity and increased turbidity (Burns et al., 2005; Galarowicz, unpublished data), higher densities of round gobies (Charlebois et al., 1997; Clapp et al., 2001; Johnson et al., 2005), and permission of angling during the smallmouth bass spawning season (Steinhart et al., 2005a) compared to the Beaver Archipelago.

Smallmouth bass nest success has not previously been fully explored in relation to nest densities and associated habitat characteristics in large lentic systems. Most studies have identified which factors influence nest survival but do not link any habitat or environmental characteristics associated 
between nest survival and nest densities. Therefore, it remains unclear if any of the same variables used to predict nest densities in a given area could also be used to predict nest success. Given the tendency of nest site fidelity in smallmouth bass, a direct link in variables used to explain nest success and nest density may suggest that smallmouth bass select habitats based on both habitat quality and prior nest success. Identifying environmental and habitat features important to nesting will allow us to predict where smallmouth bass will spawn and the likelihood of nest success in these areas. Our objectives were to quantify the number of smallmouth bass nests and nest success in a smallmouth bass population in northern Lake Michigan and relate these metrics (i.e., number of nests and nest success) to environmental and habitat variables. We hypothesized that the numbers of nests and nest survival would be highest in sites that were more protected from wind/waves and, thus, warmer in comparison to other transects sampled.

\section{Methods}

The Beaver Archipelago is located in northeastern Lake Michigan approximately 25-30 km from both the lower and upper peninsulas of Michigan (Fig. 1). Four bays adjacent to Garden Island (e.g., Sturgeon, Indian Harbor, Manitou, and Garden Harbor) were surveyed for smallmouth bass nests (Fig. 1). Bays were selected based on the diverse nature of habitat (i.e., substrate, depth, location) associated with each bay, which encompassed the spectrum of typical habitat found in the Archipelago.

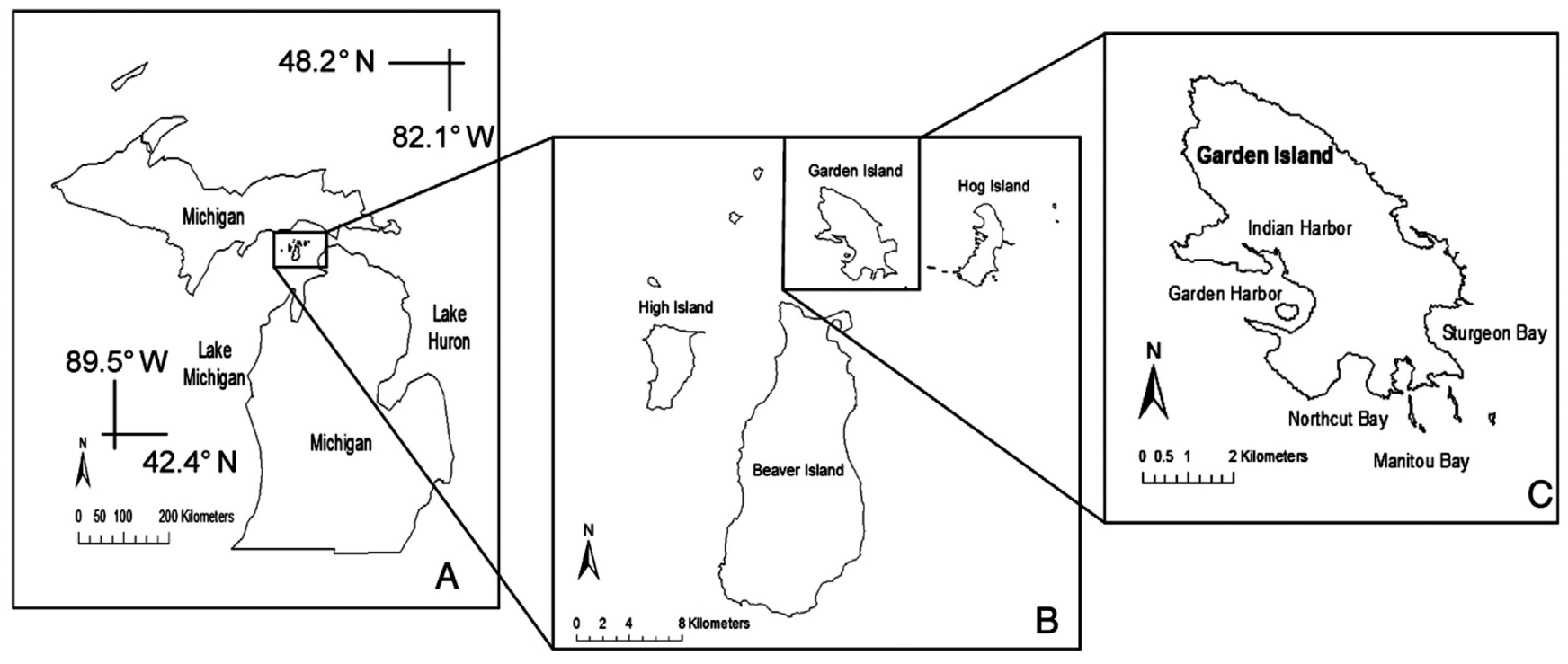

Fig. 1. Michigan (A), Beaver Archipelago (B), Garden Island and associated bays (C). 
Three $100 \mathrm{~m}$ linear transects $(6 \mathrm{~m} \times 100 \mathrm{~m})$ were randomly chosen perpendicular to shore within each bay along a contour of $0.5 \mathrm{~m}$ to $1.5 \mathrm{~m}$ total depth because previous studies have indicated smallmouth bass nest sites are frequently located within this depth range (Rejwan et al., 1999). The total number of nests is reported for each transect rather than nest densities because all transects were equal in total area searched. These transects represented the experimental unit in our study as other studies have commonly used this approach to assess which variables are associated with nest densities of smallmouth bass (Rejwan et al., 1997, 1999). Furthermore, each transect differed with respect to a majority of the variables measured (i.e., substrate firmness, effective fetch, rugosity) indicating the need to assess density estimates at this level. Smallmouth bass nests were located by snorkeling and visual observations from a boat during the last week of May (i.e., when nest development was initiated) through the first week of July 2008. Each transect was visually inspected for nests approximately every 5 days (mode $=5$, mean $=5.82$, range $=2-9$ ). Upon locating a nest, each was marked with an orange marking flag with an individual identification number. Two requirements necessitated marking a nest: eggs were visible and a male was actively guarding the nest. The status (i.e., successful, unsuccessful) of the nest was monitored over the duration of the study. A successful nest was evident by both the presence of swim-up fry (i.e., free swimming stage, frequently used to describe a successful smallmouth bass nest; Ridgway, 1989; Steinhart et al., 2005a) and a male actively guarding the nest, while an unsuccessful nest did not have visible eggs or fry and the male had vacated the nest (Philipp et al., 1997). Many nests were observed with swim-up fry for two or more sampling events, which minimized categorizing a successful nest as being unsuccessful.

Temperatures used for analyses were from hourly records from data loggers (Stowaway XTI, Onset(C) placed in each bay at a depth of $1 \mathrm{~m}$ in the middle of a transect. Cumulative degree days (CDD) were calculated for each bay as the sum of degrees by which daily mean temperatures exceeded $15{ }^{\circ} \mathrm{C}$ until the last nest was observed with swim-up fry in each bay. Fifteen degrees Celsius was chosen because smallmouth bass typically initiate spawning at this temperature (Ridgway et al., 1991b). In addition, the number of occurrences where temperatures declined $\geq 2{ }^{\circ} \mathrm{C}$ between two consecutive hourly temperatures were counted for each bay (Friesen, 1998; Steinhart, 2004).

Other habitat characteristics were measured once during peak nesting (e.g., mid-June). Substrate firmness and rugosity were measured at three locations ( $\mathrm{o} \mathrm{m}, 50 \mathrm{~m}, 100 \mathrm{~m}$ ) along each transect; mean values were calculated for each transect. Substrate firmness $(\mathrm{cm})$ was determined by placing a $9.0 \mathrm{~kg}, 4.1-\mathrm{cm}$ diameter metal pole on the lake bottom and measuring the distance it sank into the substrate (Gosch et al., 2006). Rugosity (m) was 
obtained by allowing a $6.1 \mathrm{~m}$ fine link chain to fall naturally over the lake bottom and measuring the total distance (m) (Rejwan et al., 1999). A low rugosity measurement indicated high habitat complexity. It is assumed that wave height and protection from storms was a function of fetch. Therefore, modified effective fetch was calculated for each transect using GIS software (ArcMap version 9.2; Resource Inventory Committee, 1999). Fetch distances were measured along three different angles relative to each of the transects midpoints: $90^{\circ}$ perpendicular, $45^{\circ}$ to the left and right of perpendicular. Effective fetch $(\mathrm{Fe})$ was calculated using the following formula:

$$
F_{\mathrm{e}}=\frac{\cos \left(45^{\circ}\right) * F_{45 \mathrm{~L}}+\cos \left(90^{\circ}\right) * F_{90}+\cos \left(45^{\circ}\right) * F_{45 \mathrm{R}}}{\cos 45^{\circ}+\cos 90^{\circ}+\cos 45^{\circ}}
$$

where $F_{45 \mathrm{~L}}=$ fetch distance along the transect midpoint $45^{\circ}$ left of perpendicular, $F_{90}=$ fetch distance at perpendicular of the transect midpoint, $F_{45 \mathrm{R}}$ $=$ fetch distance long the transect midpoint $45^{\circ}$ right of perpendicular (Resource Inventory Council, 1999).

We estimated the number of storms to which each nest transect was subjected over the duration of the study. A storm was defined as two consecutive hours of wind speeds $\geq 7 \mathrm{~m} \cdot \mathrm{s}^{-1}$, which was based on previous research to which smallmouth bass nests were destroyed at similar depths on Lake Erie using artificial nests (Steinhart et al., 2005a). Wind speed $\left(\mathrm{m} \cdot \mathrm{s}^{-1}\right)$ and direction $\left({ }^{\circ}\right)$ were recorded hourly from moored National Data Buoy Center station 45002 (National Oceanic and Atmospheric Administration) in northern Lake Michigan. Only winds blowing directly at each transect and not mediated by land masses were included in the analysis (Steinhart et al., 2005a). Some transects were completely sheltered (i.e., effective fetch less $800 \mathrm{~m}$ ) by waves from land masses and assumed not to be subject to the same intensity of waves as other transects with larger fetches.

Differences in the number of newly formed nests were assessed among bays, using day as the replicate, with a repeated measures one-way analysis of variance (ANOVA, ProcMixed; SAS Institute Inc., 2003). A Tukey's honest significant difference test was used to separate treatment means. We determined which environmental (i.e., CDD) and habitat variables (i.e., substrate firmness, rugosity) were related to the number of nests using an information theoretic approach (Burnham and Anderson, 1998). Multicollinearity was not evident among any of the measured variables (i.e., Pearson's $r<0.60$ ). Akaike's information criteria (AIC) was used to select which model(s) best predicted the number of smallmouth bass nests given a set of a priori selected candidate models using AICc, corrected for small sample size (Burnham and Anderson, 1998). Delta AIC $_{c}$ values and Akaike weights were used to interpret model support given the data. Delta AIC values less than two suggest substantial support for a given model and larger Akaike 
weights indicate more evidence for a model being the best model out of the set of candidate models.

Daily nest survival rate models (DSR) were evaluated using Program MARK (White and Burnham, 1999). A more complete description of methods pertaining to this type of analysis is described in Dinsmore et al. (2002). Nest survival estimation in Program MARK was chosen over the Mayfield method because it is based on statistical theory that provides maximum-likelihood estimates of the mean and variance associated with the daily survival rate. Models with an individual or time-specific covariate (i.e., CDD, number of storms, effective fetch, temperature declined $\geq 2{ }^{\circ} \mathrm{C}$ ) were modeled with the logit link function; all other models with a one-to-one correspondence with $\beta 1$ (intercept) and $S_{1}$ (survival estimate) were modeled with the sine link function (Dinsmore et al., 2002). Daily nest survival rates for the model receiving the most support were calculated from the appropriate link function using the maximum likelihood estimates of the regression coefficients and associated sampling variances. Daily survival estimates were calculated for this model using the logit link function as follows,

$$
\mathrm{DSR}=\frac{\exp \left(\beta_{\mathrm{o}}+\beta_{1}\left(X_{1}\right)\right)}{1+\exp \left(\beta_{\mathrm{o}}+\beta_{1}\left(X_{1}\right)\right)}
$$

where $\beta_{\mathrm{o}}$ is the intercept and $\beta_{1}\left(\mathrm{X}_{1}\right)$ is the individual covariate value (e.g., CDD). Nest survival for the typical duration of nest guarding for smallmouth bass was calculated by raising the daily survival rate to the power of 20 (i.e., typical successful nest duration is 20 days; Steinhart et al., 2005a). The delta method, which approximates variance of parameters that are a function of random variables (i.e., DSR as a function of CDD) was used to estimate 95\% confidence intervals (Seber, 1982; Powell, 2007). Multiple competing hypotheses relating to daily survival rates of smallmouth bass nests in the Beaver Archipelago were also tested with the information theoretic approach. Considering the principle of parsimony (Burnham and Anderson, 1998), candidate models selected a priori based on importance found in previous studies included effective fetch, number of storms, CDD, and number of occurrences where consecutive hourly temperature decreased by $\geq 2$ ${ }^{\circ} \mathrm{C}$ for each bay (Goff, 1986; Lukas and Orth, 1995; Steinhart et al., 2005a).

\section{Results}

A total of 61 nests were located and monitored during the study. The number of newly formed nests peaked in Manitou Bay earlier than in the remaining three bays (Fig. 2). The number of smallmouth bass nests averaged 8.1 nests per transect with a range of $0-32$ nests for all transects sampled (Table 1). 


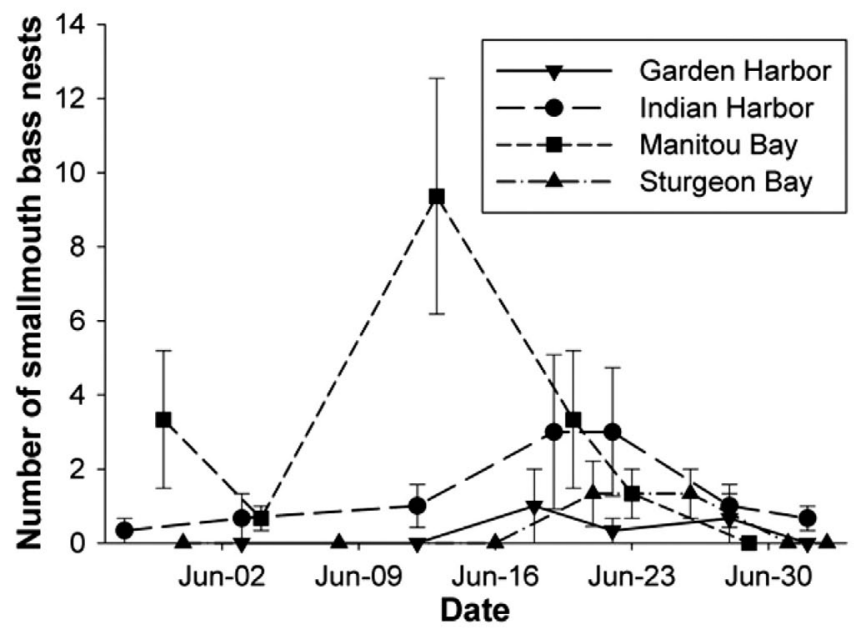

Fig. 2. Daily chronology of newly formed smallmouth bass nests in Manitou Bay, Indian Harbor, Garden Harbor, and Sturgeon Bay in the Beaver Archipelago, northern Lake Michigan.

Table 1. Number of smallmouth bass nests and environmental and habitat variables measured from each bay in the Beaver Archipelago, northern Lake Michigan. Variable means are followed by the standard error and range (low-high) in parentheses except for cumulative degree days (CDD).

\begin{tabular}{lllll} 
& Garden Harbor & Indian Harbor & Manitou Bay & Sturgeon Bay \\
\hline Number of nests & $2.00(2.00,0-6)$ & $9.67(3.84,4-17)$ & $18.00(7.21,8-32)$ & $2.67(1.45,0-5)$ \\
CDD & 20.35 & 73.84 & 66.13 & 28.13 \\
Number of storms & 0 & 0 & 0 & $1.67(0.33,1-2)$ \\
Substrate firmness (cm) & $1.33(0.77,0-2.67)$ & $2.78(1.37,0.67-5.33)$ & $2.61(1.55,0.67-5.67)$ & $0.72(0.15,0.50-1.00)$ \\
Rugosity (m) & $5.77(0.31,5.15-6.10)$ & $5.77(0.18,5.40-5.97)$ & $5.77(0.13,5.62-6.02)$ & $5.93(0.02,5.9-5.97)$ \\
Effective fetch $(\mathrm{km})$ & $4.25(3.10,0.79-10.44)$ & $0.75(0.17,0.41-0.96)$ & $0.73(0.03,0.67-0.77)$ & $11.37(4.22,3.39-17.71)$ \\
\hline
\end{tabular}

The number of smallmouth bass nests differed among bays $\left(F_{3,22}=3.63, P=\right.$ o.03). Manitou Bay contained more smallmouth bass nests compared to Garden Harbor $(t=2.84, d f=22, P=0.04)$ and Sturgeon Bay $(t=2.90, d f=22$, $P=0.04)$ but not Indian Harbor $(t=1.79, d f=22, P=0.08)$. Indian Harbor had the greatest number of CDD at 73.84 degree days (Manitou Bay-66.13, Sturgeon Bay-28.13, Garden Harbor-20.35; Fig. 3). Over 80\% (50 of 61) of smallmouth bass nests were successful with success ranging from $25 \%$ (1 of 4) in Garden Harbor to 87.5\% (14 of 16) in Indian Harbor.

The model receiving the most support in explaining the number of nests for smallmouth bass in the Beaver Archipelago was the number of CDD ( $\beta_{C D D}$ $=0.231$, Table 2 ), indicating that a positive relationship existed between nest density and CDD (Fig. 4). The next competing model, although not well 
Table 2. Model selection results for estimating the number of nests for smallmouth bass in the Beaver Archipelago, northern Lake Michigan, using Akaike's information criteria. Results include the number of parameters $(K)$, Akaike information criterion corrected for small sample bias $\left(\mathrm{AIC}_{\mathrm{c}}\right)$, differences in $\operatorname{AIC}_{\mathrm{c}}\left(\Delta_{\mathrm{i}}\right)$, and weights $\left(w_{\mathrm{i}}\right)$ for each model. Individual variables to predict the number of nests include cumulative degree days $>15^{\circ} \mathrm{C}$ (CDD), substrate firmness (firm), and rugosity (rug). Models were ranked according to lowest $\mathrm{AIC}_{\mathrm{c}}$ score. $^{\circ}$

\begin{tabular}{lllll} 
Model & $K$ & $A I C_{c}$ & $\Delta_{i}$ & $w_{i}$ \\
\hline CDD & 3 & 29.35 & 0.00 & 0.80 \\
CDD+firm & 4 & 33.85 & 4.50 & 0.08 \\
CDD+rug & 4 & 34.01 & 4.66 & 0.08 \\
rug+firm & 4 & 35.11 & 5.76 & 0.04 \\
CDD+rug+firm & 5 & 40.13 & 10.78 & 0.00 \\
\hline
\end{tabular}

Table 3. Model selection results for estimating daily nest survival of smallmouth bass in the Beaver Archipelago, northern Lake Michigan using Akaike's information criteria. Results include the number of parameters $(K)$, Akaike information criterion corrected for small-sample bias $\left(\mathrm{AIC}_{\mathrm{c}}\right)$, differences in $\operatorname{AIC}_{\mathrm{c}}\left(\Delta_{\mathrm{i}}\right)$, and weights $\left(w_{\mathrm{i}}\right)$ for each model. Individual variables to predict daily nest survival (DSR) include the number of storms during the study period (storms), number of occurrences where hourly temperature decreased by $\geq 2{ }^{\circ} \mathrm{C}$ (temp_drop), effective fetch (fetch), cumulative degree days $>15{ }^{\circ} \mathrm{C}$ (CDD), and constant survival throughout the nesting season (.). Models were ranked according to lowest $\mathrm{AIC}_{\mathrm{c}}$ score.

\begin{tabular}{lllll} 
Model & $K$ & $A I C_{c}$ & $\Delta_{i}$ & $w_{i}$ \\
\hline S (CDD) & 3 & 70.69 & 0.00 & 0.69 \\
S (.) & 2 & 73.90 & 3.21 & 0.14 \\
S (fetch) & 3 & 75.55 & 4.86 & 0.06 \\
S (storms) & 3 & 75.69 & 5.00 & 0.06 \\
S (temp_drop) & 3 & 75.75 & 5.06 & 0.05 \\
\hline
\end{tabular}

supported, included both CDD and substrate firmness. Additional competing models that included rugosity also did not receive much support in explaining variability in nest densities (Table 2).

The daily nest survival model with the most support included CDD (Table 3). The slope estimate for $\mathrm{CDD}$ was positive $\left(\beta_{\mathrm{CDD}}=0.04, \mathrm{SE}=0.01,95 \%\right.$ $\mathrm{CL}=0.008,0.07)$ on a logit scale, indicating nest survival during 20 days increased with CDD (Fig. 5). For example, a nest in a location exhibiting 24 CDD during the nesting season has a 0.26 probability of surviving 20 days, and a nest experiencing $40 \mathrm{CDD}$ has a 0.48 probability of surviving this duration. Daily nest survival rates estimated from the top model with 20.35 and 73.84 CDD ranged from 0.22 to 0.80 , respectively. Less supported models included constant survival, fetch, the number of storms nests encountered during the study, and the number of occurrences where two consecutive mean hourly temperatures decreased by $\geq 2{ }^{\circ} \mathrm{C}$ (Table 3 ). 


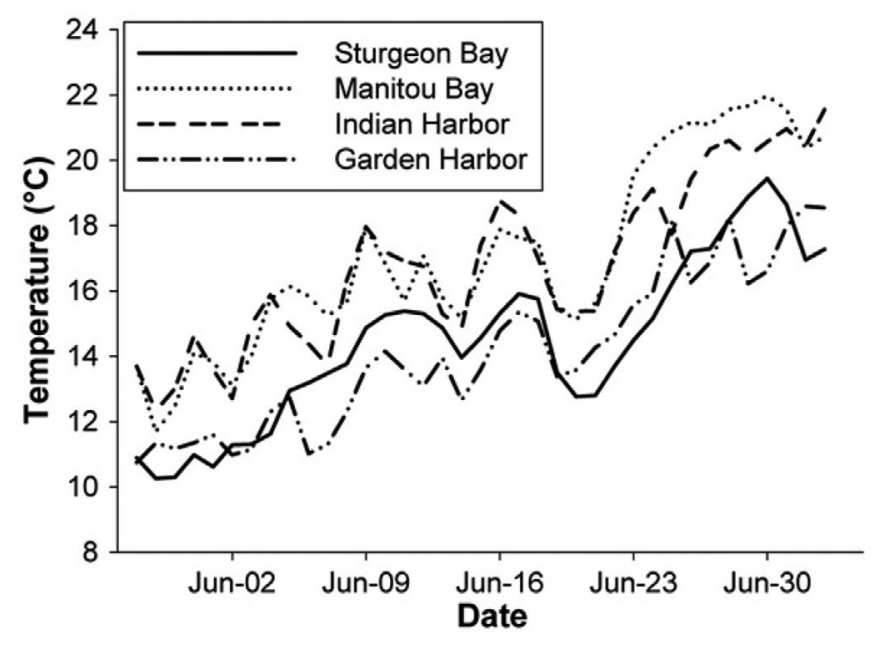

Fig. 3. Mean daily water temperatures $\left({ }^{\circ} \mathrm{C}\right)$ for Manitou Bay, Indian Harbor, Garden Harbor, and Sturgeon Bay.

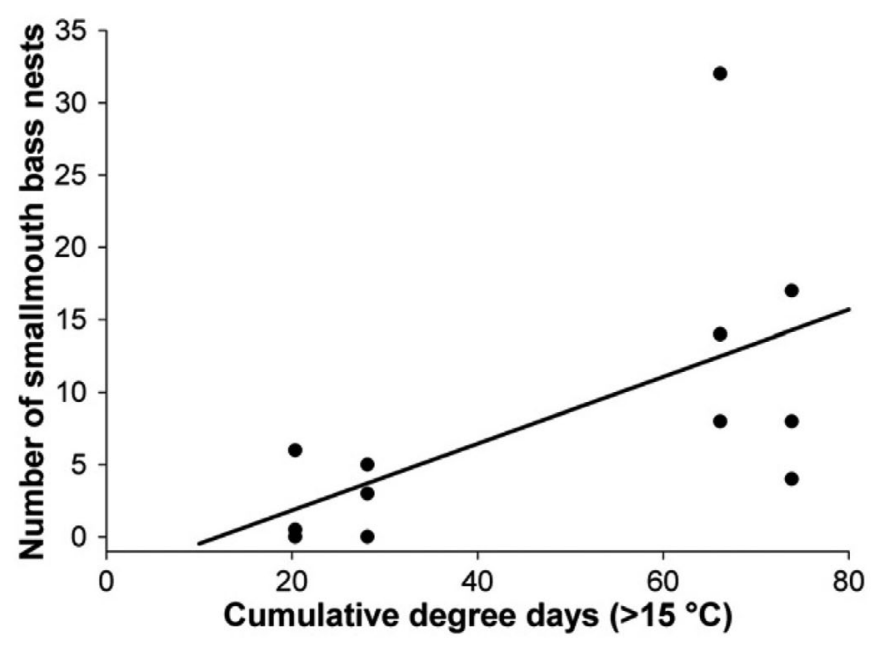

Fig. 4. Cumulative degree days $\left(>15{ }^{\circ} \mathrm{C}\right.$; CDD) plotted as a function of smallmouth bass nests.

\section{Discussion}

The number of CDD greater than $15{ }^{\circ} \mathrm{C}$ appears to be most influential in predicting the number of nests and nest survival for smallmouth bass in the Beaver Archipelago, similar to other relationships between warmer water and increased densities and survival of nests (Lukas and Orth, 1995; Rejwan et al., 1999). Our study supports the hypothesis suggested by Rejwan et al. (1999) in which nests located in warmer areas may contribute more to 


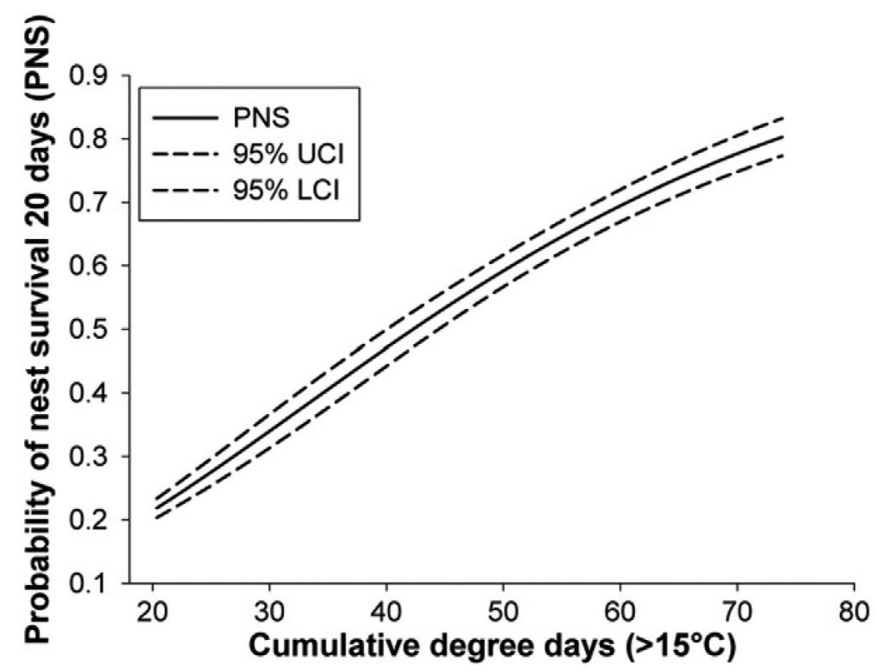

Fig. 5. Probability of a smallmouth bass nest surviving 20 days $( \pm 95 \%$ confidence intervals) as a function of cumulative degree days $\left(>15{ }^{\circ} \mathrm{C}\right.$; CDD) as predicted by the top model in Program MARK. We modeled 24-74 CDDs because this was the range of cumulative degree days given our data.

cohort strength relative to nests located in colder areas. This hypothesis is further supported because warmer areas allow increased growth rates and survival of age-o smallmouth bass (Shuter et al., 1980). Smallmouth bass nests with fewer degree days above $15{ }^{\circ} \mathrm{C}$ exhibited lower survival to the swim-up fry stage in our study. Temperature is also thought to be a limiting factor for survival during the entire first year of life (Shuter et al., 1980).

Temperature may also be related to nest site selection in smallmouth bass, which may be indirectly related to energetic demands during nesting. Activity levels of male nesting smallmouth bass are almost twice the activity level of those not providing care during the nesting period (Cooke et al., 2002) as males fan the eggs and protect them from nest predators (Blumer, 1979). To offset some of these energetic costs of providing parental care for their brood, male smallmouth bass may seek warmer areas, which will in turn allow faster development time of the eggs and larvae and allow the male to return to foraging after this energetically demanding task (Gillooly and Baylis, 1999; Mackereth et al., 1999). Therefore, temperature may directly play a role in both nest site selection and nest success in smallmouth bass, as a faster development time decreases probability that the male will experience unfavorable temperature conditions and abandon its nest (Neves, 1975; Shuter et al., 1980).

The results of our study suggest that smallmouth bass may select spawning sites based on temperature, with more nests located in locations with warmer temperatures, which may ultimately increase fitness. We hypothesize 
that Manitou Bay and Indian Harbor have contained higher densities of spawning smallmouth bass in previous years compared to other bays in the Archipelago because high nest densities among smallmouth bass appears to be tied to variables that are relatively similar among years, such as temperature (Rejwan et al., 1997). In addition, these two bays are characterized by higher relative abundance (e.g., CPUE, number/net night) of adult smallmouth bass during spawning compared to other bays in June, 2008 (Manitou Bay = 27, Indian Harbor $=23$, Garden Harbor $=8$, Sturgeon Bay $=14$; Galarowicz, unpublished data), which may be related to warmer temperatures.

Another factor thought to influence smallmouth bass nest survival was the number of occurrences where the temperature declined $>2{ }^{\circ} \mathrm{C}$ between two consecutive hours during nesting. This factor was included because rapid temperature declines may cause nest failures (Friesen, 1998; Steinhart, 2004). In contrast, Webster (1945) found smallmouth bass eggs to be resilient after subjecting them to an $8{ }^{\circ} \mathrm{C}$ reduction in temperature in a laboratory setting. However, fungus may begin to colonize eggs subjected to temperatures below $18{ }^{\circ} \mathrm{C}$ (Knotek and Orth, 1998). We found very little support for this model, most likely because most of the temperature declines (6/10) did not fall below $15{ }^{\circ} \mathrm{C}$, assuming this is the threshold below which eggs are negatively affected. Nest success was also not related to the number of storms during the spawning season as found in other studies (Goff, 1986; Steinhart et al., 2005a). This contrasting result may reflect Garden Island's central location with respect to other islands in the Beaver Archipelago. Its central location may provide more wind and wave protection than found in the Bass Islands, Lake Erie (Steinhart et al., 2005a).

We hypothesized that nest density would be greatest in areas with higher rugosity (Neves, 1975; Pflieger, 1975); however, this was not supported by our data. In lotic environments, smallmouth bass brood sites were most often located on sandy substrate as opposed to sites containing large boulders or rocky substrate (Sabo and Orth, 1994). Rejwan et al. (1999) also failed to find any relationship between nest density and rugosity in Lake Opeongo, Ontario. Habitats with higher rugosity may not be a prerequisite for smallmouth bass nest site selection, but rather may be more important at the later stages of juvenile development (i.e., protection from predation; Sabo and Orth, 1994). In addition, substrate firmness did not appear to be important for predicting nest densities among smallmouth bass in our study. Other studies have associated smallmouth bass nest selection with a firm substrate composed of coarse gravel and larger rocks (Neves, 1975; Bozek et al., 2002). The degree of variability in our measurements of substrate firmness was very low and all transects exhibited relatively solid substrate (i.e., substrate firmness $<6 \mathrm{~cm}$ ). With very little variability in substrate firmness, it may be difficult to detect a relationship between nest densities and substrate firmness. 
The results of this study suggest that both the number of nests and nest success of smallmouth bass are related to temperature regime. Habitat models that incorporate temperature may allow the identification of important spawning habitat which may correspond to high densities of spawning smallmouth bass. These areas of high nest densities could have improved spawning success. Identifying and protecting these habitats from future anthropogenic alterations could aid in the enhancement of smallmouth bass populations in large lakes.

Acknowledgments - We thank J. Clevenger for field assistance and the Michigan Department of Natural Resources and Environment Fisheries Division Charlevoix Research Station for providing assistance and temperature data loggers for the study. We thank M. Brown, D. Willis, and G. Steinhart for reviewing earlier drafts of this manuscript. We also thank two anonymous reviewers as their comments greatly improved the manuscript. We are grateful for the staff and resources available at the Central Michigan University Beaver Island Biological Station. Funding was provided by Central Michigan University administered through an Undergraduate Research and Creative Endeavors Grant to A. Clem.

\section{References}

Blumer, L.S., 1979. Male parental care in the bony fishes. Q. Rev. Biol. 54, 149-161. Bozek, M.A., Short, P.H., Edwards, C.J., Jennings, M.J., Newman, S.P., 2002. Habitat selection of nesting smallmouth bass (Micropterus dolomieu) in two north temperate lakes. In: Philipp, D.P., Ridway, M.S. (Eds.), Black bass: ecology, conservation, and management: Am. Fish. Soc., Symposium 31, Bethesda, Maryland, pp. 135-148.

Burnham, K.P., Anderson, D.R., 1998. Model selection and inference-A practical information-theoretic approach. Springer-Verlag, New York.

Burns, N.M., Rockwell, D.M., Bertram, P.E., Dolan, D.M., Ciborowski, J.J.H., 2005. Trends in temperature, Secchi depth, and dissolved oxygen depletion rates in the central basin of Lake Erie, 1983-2002. J. Great Lakes Res. 31, 35-49.

Charlebois, P.M., Marsden, J.E., Goettel, R.G., Wolfe, R.K., Jude, D.J., Rednicka, S., 1997. The round goby, Neogobius melanostomus (Pallas), a review of European and North American literature. Illinois-Indiana Sea Grant Program and Illinois Natural History Survey, Champaign.

Clapp, D.F., Schneeberger, P.J., Jude, D.J., Madison, G., Pistis, C., 2001. Monitoring round goby (Neogobius melanostomus) population expansion in eastern and northern Lake Michigan. J. Great Lakes Res. 27, 335-341.

Cooke, S.J., Philipp, D.P., Weatherhaed, P.J., 2002. Parental care patterns and energetics of smallmouth bass (Micropterus dolomieu) and largemouth bass (Micropterus salmoides) monitored with activity transmitters. Can. J. Zool. 80, 756-770. 
Dinsmore, S.J., White, G.C., Knopf, F.L., 2002. Advanced techniques for modeling avian nest survival. Ecol. 83, 3476-3488.

Friesen, T.G., 1998. Effects of food abundance and temperature on growth, survival, development and abundance of larval and juvenile smallmouth bass. Ph.D. dissertation, University of Guelph, Guelph, Ontario.

Gillooly, J.F., Baylis, J.R., 1999. Reproductive success and the energetic cost of parental care in male smallmouth bass. J. Fish Biol. 54, 573-584.

Goff, G.P., 1986. Reproductive success of male smallmouth bass in Long Point Bay, Lake Erie. Trans. Am. Fish. Soc. 115, 415-423.

Gosch, N.J., Phelps, C.Q.E., Willis, D.W., 2006. Habitat characteristics at bluegill spawning colonies in a South Dakota glacial lake. Ecol. Freshw. Fish 15, 464-469.

Johnson, T.B., Allen, M., Corkum, L.D., Lee, V.A., 2005. Comparison of methods needed to estimate population size of round gobies (Neogobius melanostomus) in western Lake Erie. J. Great Lakes Res. 3, 78-86.

Knotek, W.L., Orth, D.J., 1998. Survival for specific life intervals of smallmouth bass, Micropterus dolomieu, during parental care. Environ. Biol. Fish. 51, 285-296.

Lukas, J.A., Orth, D.J., 1995. Factors affecting nesting success of smallmouth bass in a regulated Virginia stream. Trans. Am. Fish. Soc. 124, 726-735.

Mackereth, R.W., Noakes, D.L.G., Ridgway, M.S., 1999. Size-based variation in somatic energy reserves and parental care expenditure by male smallmouth bass, Micropterus dolomieu. Environ. Biol. Fish. 56, 263-275.

Neves, R.J., 1975. Factors affecting fry production of smallmouth bass (Micropterus dolomieui) in South Branch Lake, Maine. Trans. Am. Fish. Soc. 104, 83-87.

Pflieger, W.L., 1975. Fishes of Missouri. Missouri Department of Conservation, Jefferson City.

Philipp, D.P., Toline, C.A., Kubacki, M.F., Philipp, D.B.F., Phelan, F.J.S., 1997. The impact of catch-and-release angling on the reproductive success of smallmouth bass and largemouth bass. N. Am. J. Fish. Manage. 17, 557-567.

Powell, L.A., 2007. Approximating variance of demographic parameters using the delta method: A reference for avian biologists. Condor 109, 949-954.

Rejwan, C., Shuter, B.J., Ridgway, M.S., Collins, N.C., 1997. Spatial and temporal distributions of smallmouth bass (Micropterus dolomieui) nests in Lake Opeongo, Ontario. Can. J. Fish. Aquat. Sci. 54, 2007-2013.

Rejwan, C., Collins, N.C., Brunner, L.J., Shuter, B.J., Ridgway, M.S., 1999. Tree regression analysis on the nesting habitat of smallmouth bass. Ecol. 80, 341-348.

Resources Inventory Committee, 1999. British Columbia Estuary Mapping System. Land Use Coordination Office for the Coastal Task Force Report. Resources Inventory Committee, Victoria, BC.

Ridgway, M.S., 1989. The parental response to brood size manipulation in smallmouth bass (Micropterus dolomieui). Ethol. 80, 47-54.

Ridgway, M.S., MacLean, J.A., MacLeod, J.C., 1991a. Nest-site fidelity in a Centrarchid fish, the smallmouth bass (Micropterus dolomieui). Can. J. Zool. 69, 3103-3105. 
Ridgway, M.S., Shuter, B.J., Post, E.E., 1991b. The relative influence of body size and territorial behavior on nesting asynchrony in male smallmouth bass, Micropterus dolomieui Lacépède (Pisces, Centrachidae). J. Anim. Ecol. 6o, 665-681.

Sabo, M.J., Orth, D.J., 1994. Temporal variation in microhabitat use by age-o smallmouth bass in the North Anna River, Virginia. Trans. Am. Fish. Soc. 123, 733-746.

SAS Institute Inc., 2003. SAS OnlineDoc® Version 9. SAS Institute Inc., Cary, North Carolina.

Seber, G.A., 1982. The estimation of animal abundance and related parameters, 2nd ed. Macmillan, New York.

Shuter, B.J., MacLean, J.A., Fry, F.E.J., Regier, H.A., 1980. Stochastic simulation of temperature effects on first-year survival of smallmouth bass. Trans. Am. Fish. Soc. 109, 1-34.

Steinhart, G.B., 2004. Exploring factors affecting smallmouth bass nest success and reproductive behavior. Ph.D. dissertation, Ohio State University, Columbus, Ohio.

Steinhart, G.B., Leonard, N.J., Stein, R.A., Marschall, E.A., 2005a. Effects of storms, angling, and nest predation during angling on smallmouth bass (Micropterus dolomieu) nest success. Can. J. Fish. Aquat. Sci. 62, 2649-266o.

Steinhart, G.B., Sandrene, M.E., Weaver, S., Stein, R.A., Marschall, E.A., 2005b. Increased parental care cost for nest guarding fish in a lake with hyperabundant nest predators. Behav. Ecol. 16, 427-434.

Suski, C.D., Ridgway, M.R., 2007. Climate and body size influence nest survival in a fish with parental care. J. Anim. Ecol. 76, 730-739.

Suski, C.D., Phelan, F.J.S., Kubacki, M.F., Philipp, D.P., 2002. Use of sanctuaries to protect nesting bass from angling. Am. Fish. Soc. Symp. 31, 371-378.

Switzer, P.V., 1993. Site fidelity in predictable and unpredictable habitats. Evol. Ecol. 7, 533-555.

Warner, R.R., 1988. Traditionality of mating-site preferences in a coral reef fish. Nature 335, 719-721.

Warner, R.R., 1990. Resource assessment versus tradition in mating-site determination. Am. Nat. 1135, 205-217.

Webster, D.A., 1945. Relation of temperature to survival and incubation of the eggs of smallmouth bass (Micropterus dolomieu). Trans. Am. Fish. Soc. 75, 43-47.

White, G.C., Burnham, K.P., 1999. Program MARK: Survival estimation from populations of marked animals. Bird Study 46, 120-138. 